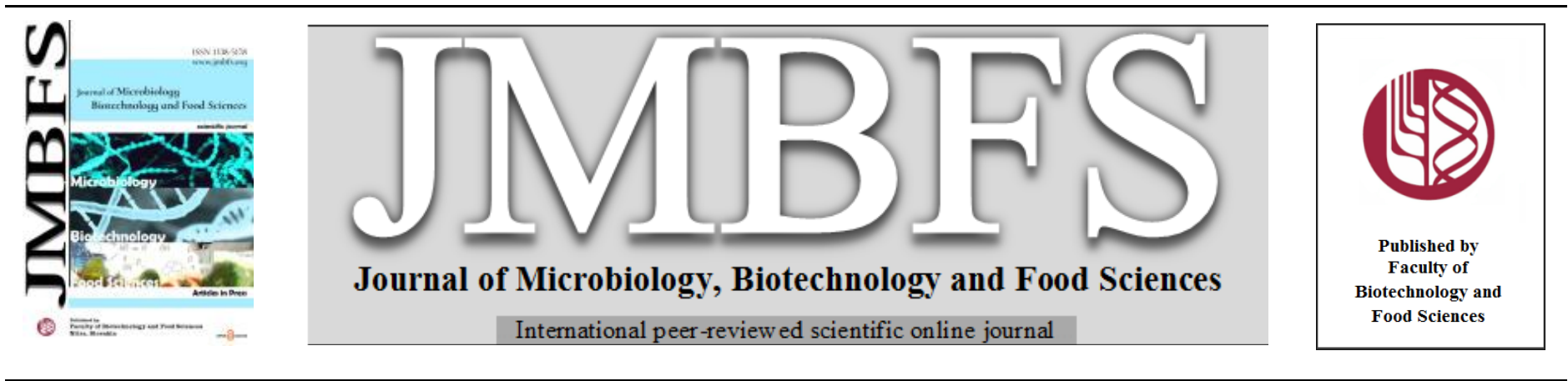

\title{
PROTECTIVE EFFECT OF CELASTRUS PANICULATUS SEEDS EXTRACT AGAINST LIPOPOLYSACCHARIDE- INDUCED PAW EDEMA IN RATS
}

\author{
K. N. Anitha ${ }^{* 1,2}$, K. M. Geetha ${ }^{*}$, \\ $\operatorname{Address}(e s)$ : \\ ${ }^{1}$ Department of Pharmacology, College of Pharmaceutical Sciences, Dayananda Sagar University, Bangalore-560078, Karnataka, India. \\ ${ }^{2}$ Department of Pharmacology, Government College of Pharmacy, Bangalore - 560027, Karnataka, India.
}

*Corresponding author: anithakn.res-shs-pharmacy@dsu.edu.in

https://doi.org/10.55251/jmbfs.4713

ARTICLE INFO

Received 27. 4. 2021

Revised 4. 2. 2022

Accepted 8. 2. 2022

Published 1. 6. 2022

Regular article

open 2 access

\section{ABSTRACT}

The present study was designed to evaluate the effect of Celastrus paniculatus seeds methanolic extract (CPME) against lipopolysaccharide (LPS)-induced paw edema and nociception in rats. Moreover, in-vitro test for soluble epoxide hydrolase (sEH) inhibition activity of CPME was conducted to study its possible mode of action.

Celastrus paniculatus seeds were extracted with methanol by cold maceration for 7 days. The obtained dark brown coloured extract was evaluated for preliminary phytochemical screening and subjected for HPTLC analysis. Then the extract was evaluated for its action against LPS-induced paw edema in rats at the dose of 100, 200 and $400 \mathrm{mg} / \mathrm{kg}$ body weight by measuring the paw edema, nociceptive bioassays and estimating 5-HETE in serum. In addition, CPME was evaluated for in-vitro sEH inhibition activity.

Administration of CPME attenuates LPS-induced paw edema by $22.85 \%$ and serum 5-HETE levels by $9.56 \%(\mathrm{P}<0.001)$ and elevated pain threshold by $112.19 \%$ ( $\mathrm{P}<0.001$ ). The CPME inhibits human, mouse and rat sEH activity with $\mathrm{IC}_{50}$ of $4.60 \mu \mathrm{g} / \mathrm{mL}, 4.17 \mu \mathrm{g} / \mathrm{mL}$ and 5.18 $\mu \mathrm{g} / \mathrm{mL}$, respectively. The present study results indicate that CPME has protective effect against LPS-induced inflammation and pain in rats. The possible mode of action is attenuation of 5-HETE levels and sEH inhibition. However, further research is warranted to elucidate and isolate the active constituents from Celastrus paniculatus seeds.

Keywords: Jyotishmati; nociceptive bioassays; Randall-Selitto test; linoleic acid; 5-HETE

\section{INTRODUCTION}

Inflammation is a complex biological response of the body to pathogens, injury, irritants or other harmful stimuli and is a part of the body's defense mechanism (Alam 2020). The purpose of inflammation is to remove the initial cause of cell injury, clean necrotic cells and damaged tissues and initiate the process of tissue repair (Rock \& Kono 2008). The persistence of inflammation for a longer duration of time may lead to painful stimuli and discomfort to the sufferers (Rock \& Kono 2008). In addition, inflammatory responses play an important role in multiple pathological conditions and pathogenesis of many diseases (Chen et al., 2018). The conventional therapies for inflammation include steroids and nonsteroid antiinflammatory drugs (NSAIDs). However, these therapies have shown many side effects and deficiencies. NSAIDs are known to cause unwanted effects like gastrointestinal disturbances, stomach ulcers, headaches, dizziness, allergic reactions, increased risk of CVS and renal complications. The steroids may cause weight gain, difficulty in sleeping, an increased risk of infections and changes in mood and behavior (Del Grossi Moura et al., 2018).

Celastrus paniculatus Willd. (Celastraceae) is commonly known as Jyotishmat and is distributed throughout Southeast Asia, India and Taiwan. The seeds of $C$. paniculatus are used in folk medicine for the treatment of analgesia, inflammation and rheumatic pain (Kothavade et al., 2015, Kulkarni et al., 2015). In Ayurveda, the seeds of $C$. paniculatus are used in the treatment of vatavyadhi i.e., diseases like arthritis and gout (Anonymous 2004). The genus Celastrus (Celastraceae) plants have been widely used in traditional Chinese medicine and Indian medicine to treat cognitive dysfunction, epilepsy, insomnia, rheumatism, gout and dyspepsia for thousands of years (Kothavade et al., 2015, Kulkarni et al., 2015).

It is reported that the seeds of $C$. paniculatus contain chemical constituents such as palmitic, stearic, oleic, linoleic and linolenic acids, sesquiterpene alkaloids (celapanin, celapanigin) and celapagin, sesquiterpene polyol ester and phytosterols including b-sitosterol, campesterol and stigmasterol (Kothavade $\boldsymbol{e t}$ al., 2015, Kulkarni et al., 2015).

Literature review reveals that flower extracts of $C$. paniculatus has been reported for their significant analgesic and anti-inflammatory activities (Ahmad et al. 1994). C. paniculatus seeds extracts were evaluated for antiarthritic effect in adjuvant-induced arthritis in rats (Patil \& Suryavanshi 2007, Kothavade et al., 2015) and carrageenan-induced acute plantar inflammation (Kulkarni et al., 2015).
Carrageenan-induced inflammation is acute and nonimmune inflammatory response (Morris, 2003). LPS-induced inflammation is the innate immune system, as well as non-immune cells, stimulated inflammatory response (Yücel et al., 2017). Systemic LPS has been identified as a pathogen-associated molecule pattern by higher vertebrates (Yücel et al., 2017). By binding to immune cells, LPS activates nuclear factor $\kappa \mathrm{B}(\mathrm{NF} \kappa \mathrm{B})$ to increase the expression of tumour necrosis factor (TNF- $\alpha$ ), interleukin-6 (IL-6) and interleukin-1 $\beta$ (IL-1 $\beta$ ) (Shaikh et al., 2016). The cytokines play an important in pathogenesis of inflammatory and pain, cytokine modulating anti-inflammatory actions can be well studied by LPSinduced paw edema model in animals (Vajja et al., 2004, Kostadinov et al., 2014). Based on the above facts, the present study was planned to evaluate the effects of methanolic extract of Celastrus paniculatus seeds (CPME) against LPS-induced paw edema in rats. A plant derived sEH inhibitor 1-(1-propanoylpiperidin-4-yl)-3(4-trifluoromethoxy) phenyl) urea (TPPU) and Ibuprofen were used as standard control for reference. Moreover, in-vitro test for soluble epoxide hydrolase $(\mathrm{sEH})$ inhibition activity of CPME was conducted to study its possible mode of antiinflammatory action.

\section{MATERIAL AND METHODS}

\section{Chemicals}

Lipopolysaccharide (LPS) and Ibuprofen were obtained from Sigma-Aldrich (USA), Rat 5-Hydroxyeicosatetraenoic acid ELISA kit was procured from Fine Test (Fine Biotech, China), A reference drug 1-(1-propanoylpiperidin-4-yl)-3-(4trifluoromethoxy) phenyl) urea (TPPU) an $\mathrm{sEH}$ inhibitor was received from Department of Entomology, University of California. All the other chemicals used were of analytical grade.

\section{Plant material and extraction procedure}

The seeds of Celastrus paniculatus were collected from the local market of Tirupati and authenticated by Dr K Madhava Chetty, Assistant Professor, Department of Botany, Sri Venkateshwara University, Tirupati (India). The voucher specimen (644) was kept in the department herbarium for future reference The dried seeds of Celastrus paniculatus $(300 \mathrm{~g})$ were coarsely powdered and extracted with absolute methanol $(1000 \mathrm{ml})$ by cold maceration process for 7 days. The solvent was evaporated and dried at $40^{\circ} \mathrm{C}$ under reduced pressure using a 
rotatory vacuum evaporator to get a dark brown colored residue (yield: $15 \%$ ). The obtained extract was stored in glass bottles at $5^{\circ} \mathrm{C}$ until its further use.

\section{Preliminary phytochemical screening of CPME}

\section{Qualitative tests}

The preliminary qualitative tests for Celastrus paniculatus methanolic extract (CPME) were performed for the detection of the presence of alkaloids (Mayer's test, Dragendorff's test, Wagner's test, Hager's test), carbohydrates (Molisch's test, Fehling's test, Benedict's test), glycosides (Legal's test, LibermannBurchard's), phytosterols (Liebermann- Burchard's test), fixed oils and fats (Spot test), saponins (Foam test), phenolic compounds and tannins (Ferric chloride test, Lead acetate test), proteins and free amino acids (Millon's test, Ninhydrin test), gums and mucilage, flavonoids (Shinoda test, Alkaline reagent test) (Trease \& Evans 1989 \& Doss 2009).

\section{Quantitative tests}

\section{Estimation of Total Flavonoids Content}

For estimation of total flavonoids, $1 \mathrm{ml}$ of extract $(0.1 \% \mathrm{w} / \mathrm{v}$ in ethanol) is mixed with $1 \mathrm{ml} \mathrm{AlCl} 3$ (2\% w/v in ethanol) and 1 drop of acetic acid was added to it and made up to $25 \mathrm{ml}$ with distilled water. Similarly, the standard quercetin in $0.1 \%$ $\mathrm{w} / \mathrm{v}$ in ethanol was treated in the same manner as a sample. The sample and the standard were allowed to stand at room temperature for $40 \mathrm{~min}$. The absorbance was measured at $415 \mathrm{~nm}$ and the readings were recorded (Trease \& Evans 1989 \& Doss 2009). Total flavonoid content was calculated using the formula:

$$
\text { Total flavanoid }=\frac{A \times M_{0}}{A_{0} \times M}
$$

where, A - absorbance of extract, Ao - absorbance of standard, M - weight of extract and Mo - weight of standard.

Estimation of Total Phenolic Content

For the estimation of total phenolic content, $1 \mathrm{ml}$ of extract was mixed with $1.5 \mathrm{~m}$ of Folin Ciocalteu's reagent and $8.5 \mathrm{ml}$ of water. Allow it to stand for $5 \mathrm{~min}$. Then $4 \mathrm{ml}$ of $20 \%$ Sodium Carbonate was added to it. The absorbance was measured at $765 \mathrm{~nm}$ and total phenolic content (TPC) was estimated using gallic acid as standard (Trease \& Evans 1989 \& Doss 2009).

\section{Estimation of Total Alkaloidal Content}

Total alkaloidal content in CPME was estimated by Gravimetric method. Briefly, quantity of extract was weighed and transferred to a separating funnel. $10 \mathrm{ml}$ of chloroform was added and the contents were shaken well for 30 minutes to extract the alkaloids completely. The contents were dried in a china dish and the residue was weighed to calculate the mass of alkaloids (Trease \& Evans 1989 \& Doss 2009).

\section{HPTLC analysis of CPME}

High-performance thin-layer chromatography (HPTLC) studies were carried out using a Camag HPTLC system with a Linomat V sample applicator, a Camag 3 TLC Scanner and WINCATS 4 software for interpretation of the data. An aluminium plate $(20 \times 10 \mathrm{~cm})$ precoated with silica gel $60 \mathrm{~F} 254$ (E Merck) was used as the adsorbent. The plates were developed using n-hexane: ethyl acetate $(5: 4)$ as the mobile phase for CPME in a Camag twin trough chamber and scanned at 254, 366 and $425 \mathrm{~nm}$. The Rf values of the CPME were determined using WINCATS 4 software. The developed plates were photo-documented at $254 \mathrm{~nm}$, $366 \mathrm{~nm}$ and $425 \mathrm{~nm}$ using a Camag 3 Reprostar. The Rf values of CPME were compared with the Rf value of standard Linoleic acid and confirmed by the overlay of spectra.

\section{Animals}

Adult Wister rats (7-8 weeks) were used in the present study. The animals were housed under standard laboratory conditions, maintained on a $12 \mathrm{~h}$ light: $12 \mathrm{~h}$ dark cycle and had free access to food and water. Animals were acclimatized to laboratory conditions before the test. The experimental protocols were approved by the Institutional Animal Ethics Committee (DSU/PhD/IAEC/12/2017-18). All the procedures performed were in accordance with Control and Supervision of Experiments on Animals (CPCSEA) guidelines, under Ministry of Animal Welfare Division, Government of India, New Delhi.

\section{Measurement of paw volumes}

After LPS challenge the volume of hind paw edema was measured at $0,1,2,3,4$, 5 and 6 h. by using a digital plethismometer (Dhadde 2019). The percentage inhibition in paw volume was calculated using the formula given below.
$\%$ paw volume inhibition

Paw volume in LPS alone group - Paw volume in test group Paw volume in LPS alone group $\times 100$

\section{Nociceptive bioassays (Randall-Selitto test)}

After paw volume measurement animals were evaluated for pain threshold at the site of inflamed paw by Randall-Selitto test using digital paw pressure analgesia meter (Orchid Scientific). The Randall-Selitto test was used to assess the analgesic effect of CPME on the response thresholds to mechanical pressure stimulation in inflammation-induced pain in the hind paw of the rat. In this test, the force was applied to the inflamed paw mechanically. When the animal responds to the pain and struggles then pressure was released and the pressure at which the animal felt pain was displayed on the TFT display was recorded. To minimize the error in the experiment, three readings were recorded and average pressure was considered as pain threshold and reported in gram force (Wagner et al., 2013).

\section{Estimation of 5-HETE in serum}

After recording paw volumes and pain threshold, a blood sample was collected from each animal by retro-orbital plexus under light ether anaesthesia. The serum was separated by centrifugation $2000 \times \mathrm{g}$ for $10 \mathrm{~min}$. The serum was used for estimation of 5-HETE by ELISA plate reader - BIORAD with kit (Fine test).

\section{In-vitro Soluble Epoxide Hydrolase (sEH) Inhibition Activity}

Dried plant extracts were solubilized at $10 \mathrm{mg} / \mathrm{ml}$ in DMSO and inhibitory potencies were measured against the mouse, rat and human sEH using a fluorescen reporting system as per the method prescribed by Jones et al., (2005). Shortly, $\mathrm{IC}_{50}$ values were determined using cyano ( 2 methoxynaphthalen-6-yl) methyl trans-(3 phenyl-oxyran-2-yl) methyl carbonate (CMNPC) as a fluorescent substrate Recombinant sEH $(1 \mathrm{nM})$ was incubated with inhibitors for $5 \mathrm{~min}$ in $100 \mathrm{mM}$ sodium phosphate buffer ( $\mathrm{pH} 7.4$ ) containing $0.1 \mathrm{mg} / \mathrm{mL}$ of BSA at $30^{\circ} \mathrm{C}$ prior to substrate introduction $([\mathrm{S}]=5 \mu \mathrm{M})$. The activity was measured by determining the appearance of the 6-methoxy-2-naphthaldehyde with an excitation wavelength of $330 \mathrm{~nm}$ and an emission wavelength of $465 \mathrm{~nm}$ for $10 \mathrm{~min}$

\section{RESULTS}

\section{Preliminary phytochemical screening of CPME}

Preliminary phytochemical screening indicates that CPME contains components such as alkaloids, carbohydrates, glycosides, proteins, free amino acids and flavonoids, whereas phytosterols, fixed oils, fats, saponins, gums and mucilage were absent.

The quantitative test results indicate that CPME contains 10.6913 QE/g (quercetin equivalent) of total flavonoids, $2.25 \mu \mathrm{g} / \mathrm{ml}$ (equivalent to gallic acid) total phenolic content and $13.24 \%$ of alkaloidal content.

\section{HPTLC analysis of CPME}

The HPTLC fingerprint studies were carried out for establishing the presence of the biomarker compound linoleic acid in CPME. The Rf value of standard linoleic acid was found to be 0.87 at $366 \mathrm{~nm}$. The CPME revealed a spot having $\mathrm{Rf} 0.87$ corresponding to that of standard linoleic acid at $366 \mathrm{~nm}$ (Figure 1). The presence of linoleic acid in CPME was confirmed by overlay spectrum study of standard linoleic acid at $366 \mathrm{~nm}$. The standard linoleic acid, CPME exhibited blue fluorescence under $254 \mathrm{~nm}$, bright blue fluorescence under $366 \mathrm{~nm}$ and no fluorescence under $425 \mathrm{~nm}$. The CPME was also evaluated for presence of linolenic acid but could not be confirmed by overlay spectrum study of standard linolenic acid at $254 \mathrm{~nm}$.

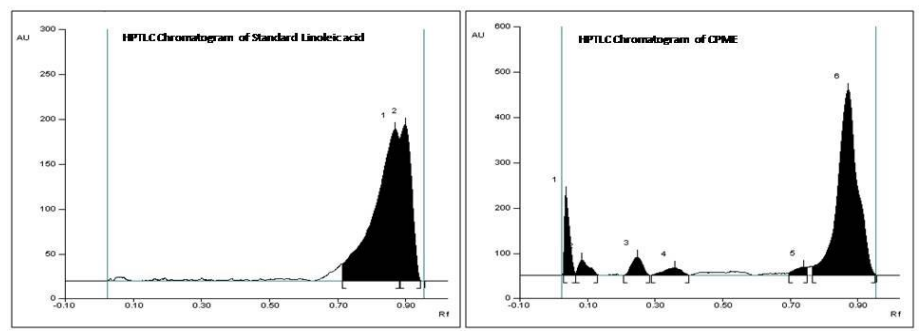

Figure 1 HPTLC Analysis of linoleic acid and Celastrus paniculatus seeds methanolic extract 


\section{In-vivo Antiinflammatory Activity}

\section{Effect of CPME on LPS induced paw edema in rat}

Table 1 depicts the result of effect of methanolic extract of Celastrus paniculatus on LPS induced paw edema in rats. The paw edema was found to be inhibited in the animals treated with all the doses of CPME at all the time points of measurements. This report suggests that CPME inhibits edema in LPS injected paw in a dose-dependent manner. Treatment with CPME at the dose of $400 \mathrm{mg} / \mathrm{kg}$ showed the highest degree of edema inhibition $(22.85 \pm 0.62)$ at $6 \mathrm{~h}$ post LPS injection interval. Inhibition of paw edema by CPME is comparable with actions produced by standard drugs ibuprofen $(30 \mathrm{mg} / \mathrm{kg})$ and TPPU $(0.1 \mathrm{mg} / \mathrm{kg})$ Treatment with CPME at the dose of $400 \mathrm{mg} / \mathrm{kg}$ is $87-89 \%$ of inhibition as that of standard drugs at all the time points. This result indicates the potent antiinflammatory actions of CPME. The results were comparable with a plant derived sEH inhibitor TPPU and Ibuprofen.

Table 1 Effect of methanolic extract of Celastrus paniculatus on LPS induced paw edema in rats

\begin{tabular}{|c|c|c|c|c|c|c|}
\hline \multirow[b]{2}{*}{ Time } & \multicolumn{4}{|c|}{ Paw volume in $\mathrm{ml}$ (\% inhibition) } & \multirow[b]{2}{*}{$\begin{array}{l}\text { Ibuprofen } \\
30 \mathrm{mg} / \mathrm{kg}\end{array}$} & \multirow[b]{2}{*}{$\begin{array}{l}\text { TPPU } \\
0.1 \mathrm{mg} / \mathrm{kg}\end{array}$} \\
\hline & $\begin{array}{l}\text { LPS alone } \\
\text { treated group }\end{array}$ & $\begin{array}{l}\text { CPME } \\
100 \mathrm{mg} / \mathrm{kg}\end{array}$ & $\begin{array}{l}\text { CPME } \\
200 \mathrm{mg} / \mathrm{kg}\end{array}$ & $\begin{array}{l}\text { CPME } \\
400 \mathrm{mg} / \mathrm{kg}\end{array}$ & & \\
\hline $\mathbf{0 ~ h}$ & $1.25 \pm 0.01$ & $1.25 \pm 0.02$ & $1.24 \pm 0.01$ & $1.26 \pm 0.02$ & $1.25 \pm 0.03$ & $1.26 \pm 0.02$ \\
\hline $1 \mathrm{~h}$ & $1.81 \pm 0.03$ & $\begin{array}{l}1.57 \pm 0.03^{* * *} \\
(13.03 \%)\end{array}$ & $\begin{array}{l}1.55 \pm 0.01^{* * *} \\
(14.15 \%)\end{array}$ & $\begin{array}{l}1.52 \pm 0.03^{* * *} \\
(15.58 \%)\end{array}$ & $\begin{array}{l}1.49 \pm 0.02^{* * * *} \\
(17.46 \%)\end{array}$ & $\begin{array}{l}1.49 \pm 0.02^{* * *} \\
(17.58 \%)\end{array}$ \\
\hline $2 \mathrm{~h}$ & $2.11 \pm 0.02$ & $\begin{array}{l}1.80 \pm 0.03^{* * *} \\
(14.45 \%)\end{array}$ & $\begin{array}{l}1.78 \pm 0.02^{* * *} \\
(15.25 \%)\end{array}$ & $\begin{array}{l}1.77 \pm 0.01^{* * *} \\
(16.23 \%)\end{array}$ & $\begin{array}{l}1.72 \pm 0.03^{* * *} \\
(18.65 \%)\end{array}$ & $\begin{array}{l}1.71 \pm 0.02^{* * *} \\
(18.89 \%)\end{array}$ \\
\hline $3 \mathbf{h}$ & $2.38 \pm 0.03$ & $\begin{array}{l}2.02 \pm 0.04^{* * *} \\
(15.03 \%)\end{array}$ & $\begin{array}{l}1.99 \pm 0.02^{* * *} \\
(16.18 \%)\end{array}$ & $\begin{array}{l}1.97 \pm 0.01^{* * *} \\
(17.18 \%)\end{array}$ & $\begin{array}{l}1.90 \pm 0.03^{* * *} \\
(19.87 \%)\end{array}$ & $\begin{array}{l}1.89 \pm 0.02^{* * *} \\
(20.58 \%)\end{array}$ \\
\hline $4 \mathrm{~h}$ & $2.49 \pm 0.02$ & $\begin{array}{l}2.08 \pm 0.02^{* * *} \\
(16.30 \%)\end{array}$ & $\begin{array}{l}2.07 \pm 0.04^{* * *} \\
(17.01 \%)\end{array}$ & $\begin{array}{l}2.04 \pm 0.02^{* * *} \\
(17.79 \%)\end{array}$ & $\begin{array}{l}1.96 \pm 0.03^{* * *} \\
(21.41 \%)\end{array}$ & $\begin{array}{l}1.94 \pm 0.04^{* * *} \\
(22.12 \%)\end{array}$ \\
\hline $5 \mathrm{~h}$ & $2.61 \pm 0.02$ & $\begin{array}{l}2.16 \pm 0.03^{* * *} \\
(17.21 \%)\end{array}$ & $\begin{array}{l}2.14 \pm 0.04^{* * *} \\
(18.13 \%)\end{array}$ & $\begin{array}{l}2.10 \pm 0.02^{* * *} \\
(19.39 \%)\end{array}$ & $\begin{array}{l}1.99 \pm 0.05^{* * * *} \\
(23.44 \%)\end{array}$ & $\begin{array}{l}1.99 \pm 0.04^{* * *} \\
(23.87 \%)\end{array}$ \\
\hline $6 \mathrm{~h}$ & $2.79 \pm 0.01$ & $\begin{array}{l}2.30 \pm 0.04^{* * *} \\
(17.63 \%)\end{array}$ & $\begin{array}{l}2.24 \pm 0.05^{* * *} \\
(19.68 \%)\end{array}$ & $\begin{array}{l}2.15 \pm 0.05^{* * *} \\
(22.85 \%)\end{array}$ & $\begin{array}{l}2.06 \pm 0.04^{* * *} \\
(26.06 \%)\end{array}$ & $\begin{array}{l}2.05 \pm 0.03^{* * *} \\
(26.52 \%)\end{array}$ \\
\hline
\end{tabular}

Values are expressed as mean \pm SEM $(\mathrm{n}=6),{ }^{* * *} \mathrm{P}<0.001$ Vs LPS alone treated rats. Two-way ANOVA followed by Bonferroni post hock test. The figures in parenthesis indicates the $\%$ inhibition of inflammation compared to LPS alone treated animals.

Effect of CPME on nociceptive response in rat

Nociceptive bioassays (Randall-Selitto test) study report suggests that LPS induces inflammatory pain in the paw and it was evident by pain threshold levels in LPS alone treated animals. Immediately after LPS injection, the pain threshold in all the groups of animals was almost equal there was no statistical difference among the groups. After that response of animals towards pain sensation changes among the groups and it was evident by pain threshold results recorded at different time points. LPS alone treated animals respond quickly to the pressure-induced pain at the inflamed paw. The pain threshold in LPS alone treated animals was recorded between 35-37 gram force where it was 42-44 gram force in normal control animal. Treatment with all the tested doses of CPME decreased the pain sensation in the animals and it was indicated by increased pain threshold in those groups of animals. The highest pain threshold was recorded in CPME $400 \mathrm{mg} / \mathrm{kg}$ dose and it was found to be 52-84 gram force at the different time interval of post LPS treatment. The pain threshold recorded in ibuprofen $(30 \mathrm{mg} / \mathrm{kg})$ and TPPU $(0.1$ $\mathrm{mg} / \mathrm{kg}$ ) were comparable with CPME $400 \mathrm{mg} / \mathrm{kg}$ dose. The detailed pain threshold at each time point interval is shown in Figure 2.

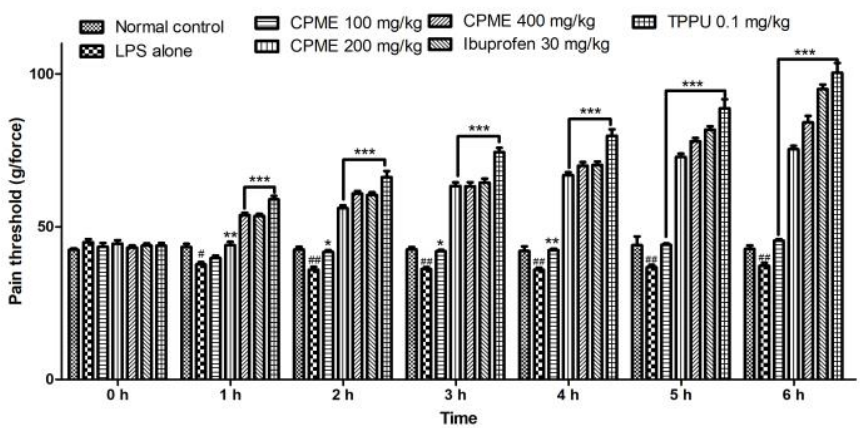

Figure 2 Effect of Celastrus paniculatus seeds methanolic extract on nociceptive response in LPS-treated rats. Values are expressed as mean \pm SEM $(n=6)$, $P<$ 0.05 and ${ }^{\# \#} \mathrm{P}<0.01$ Vs normal control and ${ }^{*} \mathrm{P}<0.05,{ }^{* *} \mathrm{P}<0.01$ and ${ }^{* * *} \mathrm{P}<0.001$ Vs LPS alone treated rats. Two-way ANOVA followed by Bonferroni post hock test.

\section{Effect of CPME on serum 5-HETE level in LPS-treated rat}

Administration of LPS elevated the levels of 5-HETE in the rat serum by $10.15 \%$ and it was found to be statistically significant $(\mathrm{P}<0.001)$ when compared to the normal control. Treatment with CPME at all the tested doses restored the 5-HETE levels towards normal compared to the LPS alone treated animals. The levels of 5 HETE in CPME treated animals were significantly $(\mathrm{P}<0.001)$ different compared to the LPS alone treated animals. Treatment with ibuprofen $(30 \mathrm{mg} / \mathrm{kg})$ and TPPU $(0.1 \mathrm{mg} / \mathrm{kg})$ to LPS challenged rats also controlled the elevation of 5-HETE significantly $(\mathrm{P}<0.05$ and $\mathrm{P}<0.001$, respectively). Figure 3 represents the effect of CPME on the levels of 5-HETE in LPS treated rats.

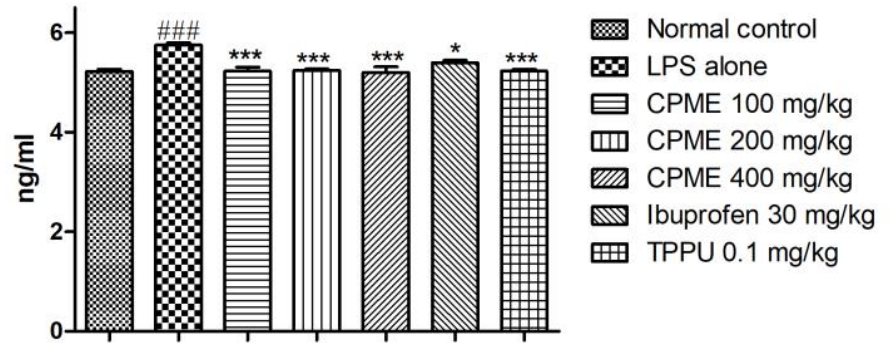

Figure 3 Effect of Celastrus paniculatus seeds methanolic extract on serum 5 HETE level in LPS-treated rat. Values are expressed as mean \pm SEM $(n=6),{ }^{\# \#} \mathrm{P}$ $<0.001 \mathrm{Vs}$ normal control rats and ${ }^{*} \mathrm{P}<0.05$ and ${ }^{* * *} \mathrm{P}<0.001 \mathrm{Vs}$ LPS alone treated rats. One-way ANOVA followed by Tukey's post hock test.

\section{In-vitro Soluble Epoxide Hydrolase (sEH) Inhibition Activity}

The in-vitro $\mathrm{sEH}$ inhibition test results reveal that CPME inhibits human, mouse and rat $\mathrm{sEH}$ enzyme. The $\mathrm{IC}_{50}$ values of in-vitro $\mathrm{sEH}$ inhibition test were found to be $4.60 \mu \mathrm{g} / \mathrm{mL}$ for human $\mathrm{sEH}, 4.17 \mu \mathrm{g} / \mathrm{mL}$ for mouse $\mathrm{sEH}$ and $5.18 \mu \mathrm{g} / \mathrm{mL}$ for rat $\mathrm{sEH}$. Figure 4 , represents the detailed results of in-vitro sEH inhibition test of CPME.

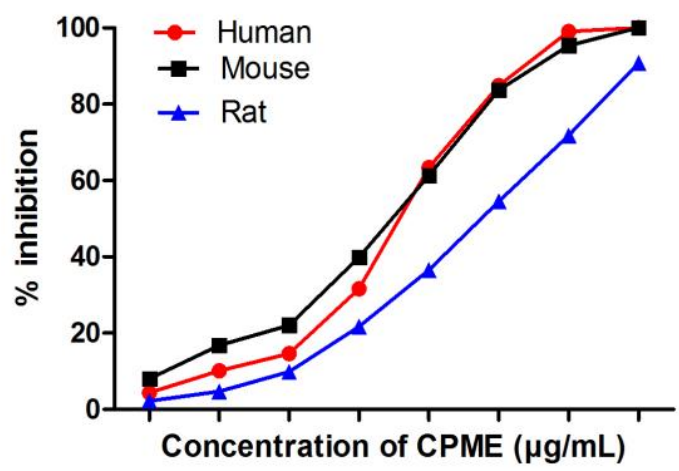

Figure 4 Effect of Celastrus paniculatus seeds methanolic extract on soluble epoxide hydrolase (sEH) activity (In-vitro test).

\section{DISCUSSION}

The present study results demonstrate that CPME protect the rats from LPS induced inflammatory response and it was evident by attenuation of paw edema elevated pain threshold and decreased 5-HETE levels in LPS-treated animals. 
These effects may be attributed to inhibition of the sEH enzyme and it was indicated by in-vitro sEH inhibition study results of CPME.

Administration of LPS to rats caused edema and pain and it was evident by increased paw volume (62\%) and decreased pain threshold (14\%) when compared with animals of normal control group. Treatment with CPME (100, 200 and 400 $\mathrm{mg} / \mathrm{kg}$ ) to LPS-treated rats attenuated the LPS-induced paw edema by $22.85 \%$ and increases the pain threshold by $112.19 \%$ compared to LPS alone treated animals. These results indicate the anti-inflammatory and nociceptive effects of CPME. 5-HETE are the eicosanoids (leukotrienes) synthesized from free arachidonic acid in presence of enzyme 5-lipooxygenase (5-LOX) after reduction of 5-HPTE and it plays important role in immune response, allergy, asthma and inflammation. 5HETE is a highly active metabolite that acts as a proinflammatory in various diseases associated with inflammation (Hanna et al., 2018). The present study results are in agreement with the above finding as there was significantly increased levels of 5-HETE (10.15\%) was observed in serum of LPS-treated animals when compared with normal control animals. Therefore, restricting the production of 5 HETE in the body is one of the targets to attack the inflammatory process Administration of CPME to LPS-treated rats attenuated the LPS-induced elevated levels of 5-HETE by $9.56 \%$ compared to LPS alone treated animals. Hence, attenuation of 5-HETE level may be one of the mechanisms through which CPME protect the animals from LPS triggered inflammation.

In addition to restricting the production of 5-HETE in the body, CPME also has inhibitory action on sEH enzyme activity. This was evidenced by $\mathrm{sEH}$ activity inhibition study conducted using human, mouse and rat sEH enzymes. It was observed that CPME inhibits human, mouse and rat sEH activity with IC50 of 4.60 $\mu \mathrm{g} / \mathrm{mL}, 4.17 \mu \mathrm{g} / \mathrm{mL}$ and $5.18 \mu \mathrm{g} / \mathrm{mL}$, respectively.

The cytochrome P450 mediated synthesis of eicosanoids yields hydroxyeicosatetraenoic acids (HETEs) and epoxyeicosatrienoic acids (EETs) The HETEs are proinflammatory on other hand EETs inhibits inflammation and associated pain. Moreover, EETs exert various beneficial effects in the body and helps in reducing blood pressure, generation of reactive oxygen species, apoptosis, pain and platelet aggregation (Harris \& Hammock 2013; Yang et al., 2015a; Yang et al., 2015b). However, EETs have a very short half-life, enzyme, sEH hydrolyzes them into their corresponding dihydroxyeicosatrienoic acids (DHETs) The hydrolyzed product DHETs have less potent compared to its corresponding EETs. Hence, inhibition of sEH enzyme activity increases the half-life of EETs as results extend its beneficial effects in the body including anti-inflammatory and anti-nociceptive actions (Wagner et al., 2013). The present study data well supports the above finding and it is evident by sEH enzyme activity and increased pain threshold in CPME treated animals when compared to the LPS alone treated animals.

Hence, anti-inflammatory and nociceptive action exerted by CPME is the combined effect of restricting the production of 5-HETE and inhibition of sEH enzyme activity by ultimately extending the half-life of anti-inflammatory mediator EETs.

The phytochemical analysis of CPME revealed that it contains the principle active constituents like alkaloids, glycosides and flavonoids and biomarker compound linoleic acid. These active compounds of CPME may be responsible for their inhibitory action on 5-HETE synthesis and sEH enzyme activity and ultimately anti-inflammatory and nociceptive actions.

\section{CONCLUSION}

In conclusion, methanolic extract of Celastrus paniculatus seeds normalized the altered paw edema, reduced the pain sensation and behaviour in LPS-treated rats, suggesting its anti-inflammatory and anti-nociceptive efficacy. The possible mode of protection may be due to its attenuation action on 5-HETE levels and sEH enzyme inhibition properties. However, further research is warranted to elucidate and isolate the active constituents from Celastrus paniculatus seeds.

\section{REFERENCES}

Ahmad, F., Khan, R.A., Rasheed, S. (1994). Preliminary screening of methanolic extracts of Celastrus paniculatus and Tecomella undulata for analgesic and antiinflammatory activities. J Ethnopharmacol 42(3):193 198. https://doi.org/10.1016/0378-8741(94)90085-X

Alam, M.B., Kwon, Y.G., Simu, S.Y., Shahriyar, S.A., Lee, S.H. (2020) Attenuation of Inflammatory Symptoms by Icariside B2 in Carrageenan and LPSInduced Inflammation Models via Regulation of MAPK/NF- $\kappa \mathrm{B}$ Signaling Cascades. Biomol 10(7):1037-1045. https://doi.org/10.3390/biom10071037

Anonymous. (2004). The Ayurvedic Pharmacopeia of India $1^{\text {st }}$ ed. Part 1. II. New Delhi: Government of India, Ministry of Health and Family Welfare, Department of AYUSH.; pp. 62-63.

Chen, L., Deng, H., Cui, H., Fang, J., Zuo, Z., Deng, J., Li, Y., Wang, X., Zhao, L. (2018). Inflammatory responses and inflammation-associated diseases in organs. Oncotarget 9(6):7204-7218. https://doi.org/10.18632/oncotarget.23208

Del Grossi Moura, M., Cruz Lopes, L., Silva, M. T., Barberato-Filho, S., Motta, R., Bergamaschi, C.C. (2018). Use of steroid and nonsteroidal anti-inflammatories in the treatment of rheumatoid arthritis: Systematic review protocol Medicine 97(41), e12658. https://doi.org/10.1097/MD.0000000000012658.
Dhadde, S. B. (2019). Handbook of Experimental Pharmacology, first ed. Studiun Press. New Delhi.

Doss, A. (2009). Preliminary phytochemical screening of some Indian medicinal plants. Anc Sci Life

https://www.ncbi.nlm.nih.gov/pmc/articles/PMC3336308/

Hanna, V. S., Hafez, E. A. A. (2018). Synopsis of arachidonic acid metabolism: A review. J Adv Res 11: 23-32. https://doi.org/10.1016/j.jare.2018.03.005

Harris TR, Hammock BD. (2013). Soluble epoxide hydrolase: gene structure expression and deletion. Gene. 526(2):61-74. https://doi.org/10.1016/j.gene.2013.05.008

Jones, P.D., Wolf, N.M., Morisseau, C., Whetstone, P., Hock, B., Hammock, B.D. (2005). Fluorescent substrates for soluble epoxide hydrolase and application to inhibition studies. Anal Biochem 343(1):66-75 https://doi.org/10.1016/j.ab.2005.03.041.

Kostadinov, I., Delev, D., Petrova, A., Stanimirova, I., Draganova, K., Kostadinova, I., Murdjeva, M. (2014). Study on anti-inflammatory and immunomodulatory effects of clomipramine in carrageenan- and lipopolysaccharide-induced rat models of inflammation. Biotech Biotech Equip. 28(3):552-558. https://doi.org/10.1080/13102818.2014.932136

Kothavade, P.S., Bulani, V.D., Deshpande, P. S., Chowdhury, A.S., Juvekar, A.R. (2015). The petroleum ether fraction of Celastrus paniculatus Willd. seeds demonstrates antiarthritic effect in adjuvant-induced arthritis in rats. $\mathrm{J}$ Trad Chinese Med Sci 2,183e193. http://dx.doi.org/10.1016/j.jtcms.2016.02.004 Kulkarni, Y. A., Agarwal, S., Garud, M. S. (2015). Effect of Jyotishmati (Celastrus paniculatus) seeds in animal models of pain and inflammation. J Ayurveda Integr Med 6:82-8. https://doi.org/10.4103/0975-9476.

Morris C.J. (2003) Carrageenan-Induced Paw Edema in the Rat and Mouse. In Winyard P.G., Willoughby D.A. (eds) Inflammation Protocols. Methods in Molecular Biology, vol 225. Humana Press. https://doi.org/10.1385/1-59259-374 7:115

Patil, K. S., Suryavanshi, J. (2007). Effect of Celastrus paniculatus, willd seed on adjuvant induced arthritis in rats. Pharmacogn Mag 3:177-81.

Rock, K.L., Kono, H. (2008). The inflammatory response to cell death. Annu Rev Pathol 3: 99-126. https://doi.org/10.1146/annurev.pathmechdis.3.121806.151456. Shaikh A, Dhadde SB, Durg S, Veerapur VP, Badami S, Thippeswamy BS, et al. (2016). Effect of Embelin Against Lipopolysaccharide-induced Sickness Behaviour in Mice. Phytother Res. 30(5):815-22. https://doi.org/10.1002/ptr.5585 Trease, G.E., Evans, W.C. (1989). Textbook of Pharmacognosy, vol. 12, Balliese Tindall and Co Publishers, London, UK.

Vajja Bhargavi, N. L., Juluri, S., Kumari, M., Kole, L., Chakrabarti, R., Joshi, V.D. (2004). Lipopolysaccharide-induced paw edema model for detection of cytokine modulating anti-inflammatory agents. Int Immunopharmacol 4(7):901909. https://doi.org/10.1016/j.intimp.2004.04.007

Wagner, K., Inceoglu, B., Dong, H., Yang, J., Hwang, S.H., Jones, P., Morisseau, C., Hammock, B.D. (2013). Comparative efficacy of 3 soluble epoxide hydrolase inhibitors in rat neuropathic and inflammatory pain models. Eur J Pharmacol 700 (1-3):93-101. https://doi.org/10.1016/j.ejphar.2012.12.015

Yang J, Bratt J, Franzi L, Liu JY, Zhang G, Zeki AA, et al. (2015a). Soluble epoxide hydrolase inhibitor attenuates inflammation and airway hyperresponsiveness in mice. Am J Respir Cell Mol Biol. 52:46-55 https://doi.org/10.1165/rcmb.2013-0440OC

Yang L, Maki-Petaja K, Cheriyan J, McEniery C, Wilkinson IB. (2015b). The role of epoxyeicosatrienoic acids in the cardiovascular system. Br J Clin Pharmacol. 80(1): 28-44 https://doi.org/10.1111/bcp.12603.

Yücel, G., Zhao, Z., El-Battrawy, I. et al. (2017). Lipopolysaccharides induced inflammatory responses and electrophysiological dysfunctions in human-induced pluripotent stem cell derived cardiomyocytes. Sci Rep 7, 2935 https://doi.org/10.1038/s41598-017-03147-4. 